\title{
5. Reflections of a First-Timer at a Provincial Rally: The Healing Power of Physical Presence and Bonding
}

ERIN ROSE

\begin{abstract}
This chapter encompasses my journey of being an impoverished student in Ontario, Canada. In this chapter, I articulate my own struggles that have shaped my identity of becoming a "youth advocate." To expand, I will also discuss the validation that is received through community building and shared experiences while at an activism event, such as the \$15 and Fairness protest. My journey went from feeling isolated in my own fight, to wanting to make a difference and having a desire to see a positive change for future generations. I will also touch on my experiences as a youth advocate in both a provincial rally setting, as well as an international youth advocacy project setting. It was not until the Tikkun Youth Symposium that I personally identified as a youth advocate. Once I saw that there were people from all different areas of the world who were in the same generation as myself, fighting for social economic justice in our separate communities, did I truly find comfortability in identifying as such while meeting some of the most special people. As youths in modern day society, it is our responsibility to heal and repair the world in the ways we best know how and to positively fight against the struggles of our communities. It is essential that experiences be shared and articulated, as well as building identification processes to feel comfortable in one's own skin as a youth advocate. Experiencing the emotion and validation that is attached to being physically present at an activism event for the first time is important as well.
\end{abstract}


Experiences of modern youth advocates portray online presence in the activism world as important, but it is not the only way to participate in youth advocacy or activism. There is a sense of community and bonding that happens at events that evolve from community organizing. The $\$ 15$ and Fairness movement is based on an anti-oppressive lens, meaning it was not led or fully supported by one group of people: various groups were fighting for the advancement of economic justice. The \$15 and Fairness movement takes place both online and in physical assembly, which is an attribute not so often seen anymore. The atmosphere of bodies and spaces is something that cannot be achieved on a strictly online activist community. The sense of friendship, community building, networking, success, and shared experiences can be found online, but the physical atmosphere of being in the middle of all the action at a grassroots event is an experience of a lifetime and belonging.

Online activism is not the only way that this generation of youth advocates can take part in having their voices expressed. We have seen the enormous potential of activism that grows out of online communities. For example, the international Occupy Movement was facilitated by online engagement, but took shape by local camps. The Occupy Movement first took place on Wall Street in October of 2011 (Democracy Now, 2011). It was a call for the nations to change the ways in which they think about and use money (Democracy Now, 2011). During this time, Wall Street was crashing, and tax payers' dollars were being used to bail out billion-dollar companies while everyday citizens were struggling to find work, and afford food, housing, education, etc. (Democracy Now, 2011). This protest not only took place in New York City, but reached an international level through online forums as a movement against social and economic inequality and a lack of democracy around the world. This is important to note because the Occupy Movement illustrates that online communities are important, but that the intimacy and connection that developed in camps is what sustained activists' commitment to the movement, so much so that they were willing to occupy spaces with their physical bodies. This point is not an argument of choosing to use one and not the other; it is about the importance of experiencing both. There is a responsibility of knowing what lights your activism on fire, and being involved in the repair of that in order to see change. My personal experiences speak to the intimacy derived through bodies and space which creates a sense of community, connection, and belonging. 


\section{Introduction}

This chapter is an autoethnographic journal of my journey that evolved from me feeling like a hopeless impoverished student who lacked a voice and a stance about injustices, into identifying as a motivated youth advocate. An autoethnographer uses photographs, life history, and biographies to give voice and explore self-revelation (Reed-Danahay, 2011). It is a chance to create a space for first-hand narratives. However, I am only speaking from my own experiences in the world thus far and realize others may have completely different experiences. With that being said, I will incorporate instances of activist history that support my experiences and self-reflection. Taking the route of autoethnography in sharing the importance of healing the world is important because I am able to create a space for shared experiences within a scholarly piece. Sharing experiences is one of the most powerful avenues in terms of sharing how one sees the world and most importantly how we can take responsibility in those experiences.

I want to share my experiences and life history to help others in similar circumstances from feeling isolated. I did not always identify as a youth activist because this label/term seemed loaded and carried a great deal of cultural baggage: trouble maker, radical, loudmouth, etc. I personally did not perceive myself in this light so I chose to not identify as such. This chapter aims to explore how I became comfortable identifying as a proud youth advocate. In this journal, I also describe the healing power of bonding with other like-minded youth and the feeling of being involved in both online and in-person activism. I will discuss my experiences as a student, both in high school and my decision to become a university student. Then, a discussion of my experiences as a campaigner for the $\$ 15$ and Fairness movement at my university and as a first-time protester at a provincial rally will follow. The chapter will then focus on my beliefs in terms of grassroots organizing within activism and speak about my transformative experience within the Tikkun Youth Project.

\section{Erin: The Student}

I started my post-secondary adventure at the University of Windsor where 
I graduated with my Bachelor of Arts in Women Studies, then continued at the same university in the Faculty of Education. Women Studies was my stepping stone for applying to the Faculty of Education because you need an undergraduate degree or equivalent to apply. Women Studies forever changed the way I viewed the world, encouraged me to do a lot of unlearning in terms of societal norms, and facilitated a home away from home for me. I was so passionately angry at the structure of post-secondary schooling that I contemplated how anyone did it. Nevertheless, I wanted to become a teacher because for however alienating and elitist universities are, I still believed in the importance of education and the impact I could have on the generations to come. Oftentimes, throughout my undergraduate education, I questioned the reasons why a university degree and obtaining a career I desire and love was so incredibly expensive.

As long as I can remember, my peers and I were told, "If you go to university, you will be guaranteed a good job." Since there was no university in my hometown, I had to think about where I was going to live and how I would afford the related expenses, such as rent, textbooks, transportation, food, etc. They didn't tell us that our savings from our high school part-time jobs would hardly suffice for the tuition of one semester, let alone books and living expenses for the next couple of years. All I have ever wanted was to be a Kindergarten teacher, so I applied to the University of Windsor and started on my post-secondary schooling journey. I was told to use as many resources as I could to get to the end-goal: graduation. I recognize my privilege in having this as an option to begin with and in no means could achieve this on my own. Thankfully, post-secondary students in Ontario can apply to a financial aid program called Ontario Student Assistance Program (OSAP). This program is funded by the federal and provincial governments and ran by the Ministry of Training, Colleges and Universities (OSAP definitions, n.d.). Students can apply by submitting their income and their parents' income in order for the website to generate the eligible amount of financial assistance she/he could potentially receive. This money will be given as a loan with interest and students will begin to pay this back once they have graduated. I was also "lucky" enough to receive a student loan from my bank as well to help with the cost of post-secondary schooling and living expenses. I am also privileged enough to have parents who have tried to support me as much as they could to help me reach my end goal.

My thought process was that I wanted to become a teacher right after I graduated which would mean that both of my loans would be paid off in no 
time. However, in order to become a teacher in Ontario, you must have an undergraduate degree to apply to the Faculty of Education which means at least four years for my undergraduate degree and another two years in the Faculty of Education. According to The New York Times, 41\% of students do not finish an undergraduate degree in four years, even though it seems that straightforward (Kolodner, 2017); I am included in that $41 \%$ and had to return for an extra semester. Personally, this put me at a total of seven years of schooling, with one more to complete. I have estimated my total debt to be approximately $\$ 70,000$ at the end of my seven-year journey. Further into my post-secondary schooling, it became apparent that there would not be a job waiting for me at the end of the proverbial tunnel. On top of post-secondary school stress, I now had the stress of $\$ 70,000$ on my shoulders and no job. There is also the pressure from society to get on with my life. I will be 26 years old by the time I graduate. To put it in perspective, my parents were 21 years old when they got married, 24 years old when they bought their first home, and 27 years old when they started having children. This was average for their generation. There is no way that I will be able to buy a car, own a house, get married, or have children with the amount of school debt I have on my shoulders. In fact,

When the first Millennials reached 30 years old back in 2010, their unemployment rate was $12.7 \%$, higher than the unemployment rate experienced by Baby Boomers and Gen. Xers when they reached the same age. In general, higher levels of educational attainment are associated with lower unemployment, job stability and higher incomes - key variables in assessing credit worthiness and demand for financial services. (Nava, Karp, \& Nash-Stacey, 2014)

I also feel the pressure to be looking for and attaining a job within my field before hitting the age of 30 in order to not feel entirely crippled due to the above facts.

I am fully aware and very lucky that my parents and sister have been supportive in helping me follow my dreams of becoming a teacher. They have taught me that my happiness and enjoyment of life should always be my first priority and I try to remind myself of this every day. I also have a strong support system within my close-knit friend group that has helped me get through the tough times. I mention this because it has kept me grounded when getting overwhelmed with thoughts of defeat, debt, and my unknown 
future. To be honest, I try to put my debt and my lack of "adulthood" out of my mind, and instead focus on the now.

Following graduation, and with no guarantees of a job in my profession, I will have to find a job that pays minimum wage in order to keep up with my loan payments for both OSAP and the bank. With minimum wage at $\$ 11.60$ an hour, I feel like I have been set up to fail by both the government and the structure of post-secondary schooling. As much as parental co-residence sharing a residence with parents and an adult child (Dettling \& Hsu, 2017) - can be an alternative to paying back debts easier, it is also a setback in order to begin my own life. Living on my own is not possible while working a precarious job with a minimum wage salary and with the debt I now have. The post-secondary school structure, in combination with the low minimum wage rates, leave students below the poverty line instead of being guided into beginning our adult lives.

How are millennials supposed to thrive and contribute to a positive world when society is not on our side? We are forced into debt in order to attain a "well-respected" job through post-secondary prices and a low minimum wage. I felt isolated, exhausted, impoverished, and incredibly stressed just thinking about it. I truly grappled with my personal morals of feeling absolutely trapped in trying to reach my set goals in modern society. It became so overwhelming at times that I contemplated quitting school all together and committing to a career I did not see myself happy in. It is unjust to expect people in the millennial generation to succeed when they are stuck with thousands of dollars of debt, with more and more businesses involving precarious work and paying a low minimum wage. This was when my passionate anger needed to be put to good use; I was then introduced to the $\$ 15$ and Fairness movement through my involvement with the Tikkun Youth Project research group at The University of Windsor.

\section{Erin: The Campaigner}

One of my professors, Dr. Frances Cachon, saw my intense passion for seeking a positive social change for myself and others in my generation; she asked if I would be interested in joining the Tikkun Youth Project and provided me with the necessary information - I was hooked. From there I joined the rest of the University of Windsor students from the Social 
Sciences and Humanities Research Council (SSHRC) funded partnership known as the Tikkun Youth Project. Tikkun Olam, the main principle of the project, is an ancient Jewish concept meaning it is our responsibility to repair and heal the world. The project consisted of five groups of youth advocates; from Windsor, South Africa, Kosovo, Thunder Bay, and Toronto. The project brought together youth from all over the world to share their experiences and issues faced within their communities. After attending my first meeting with the Windsor youth, we all felt a sense of concern about economic justice and what society had in store for our futures. With the youth participants becoming known as Tikkuners, we decided to make the \$15 and Fairness movement our focal action project. I remember feeling so heard and "at home" after I left my first meeting with the Windsor Tikkun team.

We developed our own $\$ 15$ and Fairness collective at the University of Windsor. The $\$ 15$ and Fairness movement is a provincial movement that focuses on six main demands: a \$15 minimum wage, paid sick days, rules that protect everyone in the workplace, decent hours for decent work, the right to organize and unionize, and respect at work (Demands, n.d.). This movement became my movement. I learned so much about how the minimum wage and rights in the workplace can and do affect students, families, and citizens. In Ontario, our minimum wage puts more than half of our population under or directly on the poverty line (Demands, n.d.). Is it socially just if modern day society supports the fact that families can hardly afford to live in the world we have created for ourselves?

As a collective, we advertised online about our events being held on campus where we tabled for $\$ 15$ and Fairness. Tabling is a term used in the activist community that is a public education outreach initiative aimed at bringing awareness and networking to those who want to get involved. We set up our table in the student center, ready with our signs, petitions, and buttons. These tabling events happened a few times over the span of a couple of months. We also took the time to speak in large lecture halls and classrooms on the university campus about the $\$ 15$ and Fairness movement, and informed students about the different ways in which they could become involved. During these quick 5-minute periods before a class would begin, I would open up about my extreme debt, my struggles as a student, and the bleak prospects about finding a suitable job that would enable me to pay off my loans. I would then bring up the demands of the movement and put them into the perspective of how they could assist students in paying back 
their debts. This act of sharing personal experiences was difficult for me at first, but I believed in being honest about my own experiences. I learned that it was a great way to build rapport with other students and in turn help them feel less isolated or exhausted. I knew that my impact at this point was not large; I may have sparked an interest or a light bulb in one out of twohundred of those students in each lecture hall. I may not have caught the attention of every student and my struggles may not have aligned with all of them, but to me, that one person was enough. Every small act counts in the process of Tikkun. As I became a part of this Tikkun partnership, I learned that we may not always achieve everything we set out to achieve through activism, but the small steps towards healing and repairing the world do/will make a difference.

I would describe our tabling events as a success. We had many people who were opposed to the movement come by to have conversations with us about our thoughts on inflation or on how we expected this movement to become successful in the current economy. During these conversations, it was hard to feel like we were successful, but when standing up for social movements, educational discussions are the best way to get the information and importance across. In a study done at the University of Colorado about student protests, negotiation, and constructive confrontation, the researchers concluded that constructive confrontation can be the best approach when both parties are committed to research, analysis, debate, and dialogue (Burgess \& Burgess, 2001). My experiences with tabling at the University of Windsor also showed this as being the most comfortable way to go about listening to different viewpoints on this issue. Giving each person the time to speak and educate the other is the best way to learn about an issue, no matter what side you stand on. Burgess and Burgess (2001) also concluded that, "miscommunication and misunderstandings portray inaccurate (usually negative) images of the positions and actions of others" (p. 1); therefore, approaching such a situation can encourage growth for both sides instead of a negative experience and resisting any further dialogue. Having learned this through my own experiences with tabling events, I learned to know the facts, be well-versed in the topic, and to keep an open mind as to where the other side may be coming from. After our first event, I was presented the opportunity to attend a $\$ 15$ and Fairness rally in Toronto. I thought: "What better way to become completely equipped with the language and tools I would need to feel more confident in constructive 
confrontation than to collect this information first hand from the passionate organizers and supporters themselves?"

\section{Erin: The Protester}

The $\$ 15$ and Fairness movement organized a protest in Toronto, Ontario in October 2016. Dr. Frances Cachon, who introduced me to the Tikkun Youth Project and \$15 and Fairness, was the same person who encouraged me to attend the rally. I had never been to a rally before, so I had no idea what to expect or how to prepare. I did very little research before I went, but made sure I packed a bag with what I thought would be the essentials: band-aids, a selfie stick, a rain poncho, an extra pair of socks, my cellphone, a portable charger, a water bottle, a granola bar, cash, and my ID. Since I would be in another city with a group of strangers, I had no idea what to expect. Luckily, a friend from school decided he wanted to join me. I felt somewhat better knowing that I would be walking into this new situation with a friendly and reliable face. So, that was how I prepared and embarked on a four-hour bus ride to my very first rally. And it was not a small local rally, but a provincial one! I was amazed at the huge crowd gathered outside of Queen's Park, the provincial legislature. As I walked into the crowd, there were speakers on stage encouraging the crowd to repeat chants back to them: "We want 15 and we want it NOW!" I had chills come over my entire body, not just because of the rain or the dampness of the day, but because of the rumbling of the ground from the constant cheering; I could feel it in my heart.

Navigating around the main areas was difficult: there were hundreds and hundreds of people gathered together all for one cause, movement, and a shared struggle. There were booths and tents set up where volunteers were handing out petitions and information. There were individuals carrying large art pieces, groups with banners, and even families with children! I found it so empowering that parents would bring their children to such an event; I imagined my future self, bringing my own children out to rallies one day. There were also all kinds of people representing many different disciplines and professions: union workers, teachers, students, flight attendants, janitors, hospital staff, lawyers, and rappers.

The rain did not put a damper on or discourage a single person who was there. Even though I am short 4'10", I pushed my way through the crowd 
to get to the front of the stage. At the time, Fred Hahn, President of the Canadian Union of Public Employees (CUPE) was giving a speech. I happened to turn around to see the crowd behind me; all I saw was a sea of posters and signs, with people cheering and blowing whistles (see Appendix). I can still remember that exact moment - the happiness I experienced for not being the only one who felt like I was existing to fail and forever be in debt. This rally represented the voices of people who were struggling due to economic injustices that went beyond just students and the financial burdens they carried. I felt a strong sense of community with hundreds and hundreds of strangers, and realized that economic injustices have wide-felt ramifications.

While listening to the stories of people around me, I understood that I was not alone. This rally turned into a healing process for me. I was able to reconcile with myself and come to my own self-revelation that I no longer needed to feel alone in this fight. We marched into the street and closed down an entire intersection in the busy metropolis of Toronto. Of course, I had seen such rallies in the newspaper or on television prior to my participation in this rally, but there really were no words as to what it actually feels like to be completely immersed in a sea of people, chanting the same demand, making a ton of noise, and seeing a city intersection come to a complete halt. I could not stop smiling. "Watch me make a difference," was all I could think.

There was no one in charge at this rally, not one person who would take the blame or be held accountable, but a completely grassroots event. Grassroots activism can be described as a group of people that are not attached to any political party who are willing to put in the effort to effect a change of a shared specific injustice (Crystal, 2018). That is not to say that political persons are not involved in the movement, but that its community does not rely on political persons to organize and be in charge (Crystal, 2018). Most grassroots events are also known as peaceful protests. Brian Martin (1982) states that, "A foundation stone of activities by grassroots organisations is nonviolent action" (p. 78). This means that there are no extreme lengths or any actions of danger that are to happen at these events. This \$15 and Fairness rally was exactly that. 


\section{Erin: The Grassroots Advocate at Heart}

As we know, in the era of President Donald Trump, protests and rallies have become apparent within the news, but until recently, millennials were taking part in an action referred to as online activism. This is where tactics such as, "[v]irtual petitions, online money-bombs, forums to debate issues, and the use of social media and email" (Rohlinger, 2012, para. 1) have come into play. These tactics were used to recruit people for meetings and protests, and to spread awareness about specific issues. Rohlinger (2012) suggests that today's political activists try to engage citizens and influence the political process through online activism. As much as I believe that this is a great way to grab the attention of large masses of people and is extremely convenient, the atmosphere of bodies in spaces is something that cannot be achieved through a strictly online activist community. Of course, the sense of friendship, community building, networking, success, and experience sharing can be found online, but the physical atmosphere of being there in the middle of all the action at a grassroots event is an experience of a lifetime that provides a sense of belonging.

Online activism is one way, but not the only way, that this generation of youth advocates can take part in having their voices expressed. When looking at the Occupy Wall Street movement, for example, the online presence was a network of protesters and activists who gathered on social media to share the intense experience of unfair political and economic order (Caren \& Gaby, 2011). Their online activism spoke highly of their volume and were able to connect with people nationally without meeting them in person, but also participating locally at the same time (Caren \& Gaby, 2011). This strengthens the idea that both online and physical participation can be useful in tackling social injustice. Getting out there is important in order to feel the sense of community, rather than watching numbers increase online and thinking that is enough. Choosing one or the other is not the argument here, but rather the importance of experiencing both. To physically attend a rally is a different atmosphere and overall feeling compared to the gratification of involvement through likes or shares on social media. There is truly something magical about attending a rally. It brought a sense of accomplishment because I had actually been there, took up space, and showed my support by wearing my struggle on my sleeve. Being a part of a community that I had never thought I would become a part 
of was a great stepping stone into realizing who I wanted to be, and already was, as an advocate.

\section{Erin: The Tikkuner}

I felt an even greater sense of community and belonging when I met my fellow international Tikkuners at the Tikkun Youth Project conference and symposium in April of 2017. I had never been surrounded by other youth who also wore their struggles on their sleeves, who weren't afraid to speak up about their issues in their communities, and who were just as passionate as myself when it came to activism - maybe even greater! I met people who saw the world as our world and who wanted to make a change by repairing what had been broken in our individual societies.

On the first day of rehearsals for the Artnote ${ }^{1}$ when we presented our singular pieces that we all prepared, I was in tears. I could feel the passion beaming out of every single member of the groups at each partnering site. We were there to stand up for the things we found most important and to show them off to the other passionate beings that we were surrounded by. I was so proud of these strangers right from our first day together. Meeting my new found Tikkun family was one of the most impressionable moments of my entire life. I am forever thankful for the love, support, and courage of my fellow Tikkuners. On our last day together when we performed our Artnote and when our performance finally came together, it was more beautiful than I had ever imagined. The tears streamed down my face again because I felt completely overwhelmed, proud, and loved; I also felt a pure sadness because I realized it may be a long time before I see these beautiful people again. I was finally introduced to the youth advocates who weren't the stereotypes of being radical, loud mouths, or troublemakers. I saw a group of youth who were strong-willed, passionate, caring, full of life, loving, angry, but not violent, and most of all a community. Through each of the five sites, learning about the specific injustices in their communities, we still shared an overarching theme of taking on the responsibility to repair and heal the world in which we live in as youth. Not only was it about healing the world, but we also helped each other heal. We were there for each other and still are to this day. I am thankful for the friendships, for the messages of "I miss you," "I love you, but..." and for the unplanned video calls to and from my 
fellow Tikkuners. This symposium and wonderful youth gave me the courage and the community I needed in order to feel comfortable in my own skin as a youth advocate.

\section{Erin: The Youth Advocate}

Although I am still exhausted, impoverished, and incredibly stressed, I no longer feel isolated or alone. I have a community that supports me, is there for me, and understands my struggles. I have support from all sides of the world and experienced what it feels like to be in a crowd of strangers, but feel more at home than ever. I have an understanding of my responsibility as a youth advocate, as a Tikkuner, as an ally, and as a fellow youth advocate. I know my place is within grassroots organizing, and in attendance to events, protests, and rallies. I know my advocacy has meaning and a voice. I am powerful because of my community. I am a proud youth advocate.

\section{Appendix}

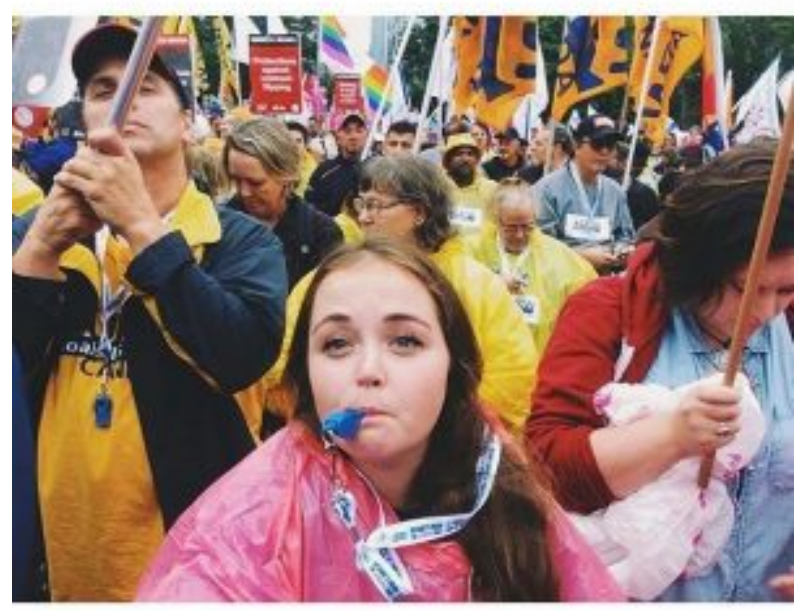




\section{References}

Burgess, G., \& Burgess, H. (2001). Student protests, negotiation, and constructive confrontation. Conflict Management in Higher Education, 2(1). Retrieved from http://www.campus-adr.org/cmher/reportarticles/ Edition2 1/Burgess2 1a.html

Caren, N., \& Gaby, S. (2011). Occupy online: Facebook and the spread of occupy wall street. Retrieved from https://papers.ssrn.com/sol3/ papers.cfm?abstract id=1943168

Crystal, G. (2018, August 5). Grassroots activism. Civil Rights Movement. Retrieved from http://www.civilrightsmovement.co.uk/grass-rootsactivism.html

Demands. (n.d.). Retrieved from https://www.15andfairness.org/demands

Democracy Now. (2011, October 10). Occupy Wall Street emerges as "first populist movement" on the left since the 1930s. Democracy Now! Retrieved from $\quad$ https://www.democracynow.org/2011/10/10/ occupy_wall_street_emerges_as first

Dettling, L. J., \& Hsu, J. W. (2017). Returning to the nest: Debt and parental co-residence among young adults. Labour Economics, 54, 225-236. doi:10.1016/j.labeco.2017.12.006

Kolodner, M. (2017, April 6). 6 reasons you may not graduate on time (and what to do about it). The New York Times. Retrieved from https://www.nytimes.com/2017/04/06/education/edlife/6-reasonsyou-may-not-graduate-on-time.html

Martin, B. (1982). Grassroots action for peace. Social Alternatives, 3(1), 77-82. Retrieved from https://www.uow.edu.au/ bmartin/pubs/82sa.html

Nava, M., Karp, N., \& Nash-Stacey, B. (2014, December 16). The Millennials paradox. BBVA Research. Retrieved from https://www.bbvaresearch.com/ wp-content/uploads/2014/12/141216 US BW BankMillennials.pdf

OSAP definitions. (n.d.). Retrieved from https://www.ontario.ca/page/osapdefinitions\#section-28

Reed-Danahay, D. (2011). Autobiography, intimacy and ethnography. In Atkinson, P., Coffey, A., Delamont, S., Lofland, J., \& Lofland, L. (Eds.), Handbook of ethnography (pp. 407-425). doi:10.4135/9781848608337

Rohlinger, D. (2012, January 1). How political movements are using the Internet to change politics. Scholars Strategy Network. Retrieved from 
http://www.scholarsstrategynetwork.org/brief/how-social-movementsare-using-internet-change-politics

1 The Artnote was a 45 minute long artistic presentation of all of the youth's research and experiences put together. This was chosen as the alternative to a keynote speaker to showcase the research done within the Tikkun Youth Project. It involved dancing, singing, drama, drawing, video, instruments, and story-telling, to show the real-life experiences of international youth struggles. Each group came prepared with a piece(s) to contribute. During the conference we were given time to rehearse, combine all of the pieces, collect props, work with light and sound, and memorize lines. 